\title{
Mats of colourless sulphur bacteria. II. Structure, composition of biota and successional patterns
}

\author{
Catherine Bernard*, Tom Fenchel ${ }^{* *}$ \\ Marine Biological Laboratory, University of Copenhagen, Strandpromenaden 5, DK-3000 Helsingør, Denmark
}

\begin{abstract}
Mats of colourless sulphur bacteria from a relatively exposed shallow water sediment and from a deeper, more protected sediment were studied. In the exposed habitat, patches of white sulphur bacteria had a limited lifetime and displayed a characteristic succession in which small sulphur bacteria (Thiospira, Macromonas) dominated at first followed by Thiovulum, which was eventually displaced by Beggiatoa; during summer phototrophic organisms dominated. Thiovulum films were only $\sim 0.2 \mathrm{~mm}$ thick and the projected area of the cells covered only 7 to $36 \%$ of the sediment surface while mats of filamentous bacteria were thicker and represented a higher biomass. In the protected locality the Beggiatoa mats were $-0.6 \mathrm{~mm}$ thick and represented a 10 -fold higher biovolume than those from the exposed habitat. The projected area of the filaments covered 2 to $3 \times$ the surface area of the sediment and had a combined length of 10 to $70 \mathrm{~m} \mathrm{~cm}^{-2}$ The mats had a porosity of 90 to $95 \%$ and did not contain a mucous matrix. Phototrophs (mainly filamentous cyanobacteria and diatoms) were always present. Protozoan biota included more than 80 species and represented a high cell density (correspondlng to $10^{4}-10^{5}$ cillates $\mathrm{ml}^{-1}$ in addition to flagellates and lobose amoebae). Many species depended on sulphur bacteria for food. The mats sometimes also harboured several representatives of meio- and macrofauna.
\end{abstract}

KEY WORDS: Microbial mats Colourless sulphur bacteria Chemoautotrophic production Protozoa Successional patterns

\section{INTRODUCTION}

Characteristic white patches of chemoautotrophic sulphur bacteria develop when free sulphide reaches the surface of aquatic sediments. The bacteria which form such microbial mats have drawn attention with respect to various physiological properties (for references see Fenchel \& Bernard 1995b). However, regarding the composition and structure of shallow water mats the literature is limited (e.g. Jørgensen 1977, Møller et al. 1985). With respect to the associated biota and the role of chemoautotrophic production for phagotrophs the literature is also quite restricted. Fauré-Fremiet (1951) described the ciliate fauna of limnic Beggiatoa mats. Fenchel $(1968,1969)$ described some marine Beggiatoa mats and their protozoan biota and showed that many

- Present address: School of Biology A08, University of Sydney, Syndey, New South Wales 2006, Australia

- Addressee for correspondence.

E-mail:marilab@inet.uni-c.dk species depend on sulphur bacteria for food. It has been shown that protozoan species isolated from mats of colourless sulphur bacteria show chemosensory behaviour with respect to $\mathrm{O}_{2}$ tension allowing them to maintain their position within the 0.2 to $0.6 \mathrm{~mm}$ thick mats (Fenchel \& Bernard 1995a). In contrast to deep sea hydrothermal vents (e.g. Tunnicliffe 1991) only few, and in part anecdotal, accounts of the role of sulphur bacteria for animals in shallow water mats exist (Perkins 1958, Thane-Fenchel 1968, Fenchel 1969, Stein 1984).

In a previous paper (Fenchel \& Bernard 1995b) we described mats of colourless sulphur bacteria with respect to fluxes of $\mathrm{S}^{2-}$ and $\mathrm{O}_{2}$. It was shown that in 2 localities consumption of chemoautotrophic sulphur bacteria corresponded to about 50 and 10 to $30 \%$, respectively, of the $\mathrm{O}_{2}$ consumption which is not directly involved in $\mathrm{S}^{2-}$ oxidation; chemolithotrophic production therefore represents an important basis for the food web. In the present paper we describe the physical structure of the mats, successional patterns in their development, and the composition of the bacterial and protist biota. 


\section{MATERIALS AND METHODS}

Sediment cores were collected in Helsingor North Harbour, Denmark, at $6.5 \mathrm{~m}$ depth (the protected locality) and in Nivå Bay, Denmark (the exposed locality) during the period April 1994 to April 1995; some supplementary samples were also collected in shallow water in the inner part of the harbour. The sites and methods of collection are described in Fenchel \& Bernard (1995b). In the laboratory quantitative subsamples were taken with a thin-walled plastic cylinder (diameter $3.5 \mathrm{~mm}$, length $2 \mathrm{~cm}$ ). It was pushed a few millimetres into the sediment from above and the mat (corresponding to $0.096 \mathrm{~cm}^{2}$ ) was removed with a Pasteur pipette and transferred to a test tube with $10 \mathrm{ml}$ $0.4 \%$ formaldehyde and a drop of an acridine orange solution in particle-free seawater. After vigorous shaking followed by 1 to $2 \mathrm{~s}$ in which mineral grains were allowed to settle, the supernatant was filtered through a black $0.2 \mu \mathrm{m}$ Nuclepore filter. The filter was rinsed by drawing a few millilitres of distilled water through the filter which was then mounted with paraffin oil between a slide and a coverslip. The transfer by the pipette and the subsequent shaking of the fixed sample was usually sufficient to make even thick mats of filamentous bacteria fall apart and the constituents of the mats were usually distributed evenly on the surface of the filter. Organisms were enumerated under the fluorescence microscope using blue excitation light (or green light for cyanobacteria). Ciliates, bacterial filaments and Thiovulum cells were counted using a 10 or $20 \times$ objective; the entire filter (or sometimes half of the filter) was counted. For the smaller components a 40 or $100 \times$ immersion objective was used and 10 or 20 fields were counted. Filamentous bacteria were quantified as the total length within $0.4 \times 0.4 \mathrm{~mm}$ squares on the filter. Results are expressed as cells $\mathrm{cm}^{-2}$ mat or as total filament length $\mathrm{cm}^{-2}$ mat. Biovolumes of different species or groups of species were estimated from linear dimensions of living cells. With respect to Beggiatoa, filaments seemed to occur in discrete size (diameter) classes; for calculation of biovolume we therefore grouped them into $2,5,10$ or $30 \mu \mathrm{m}$ diameter classes; Fig. 1D shows the range of filament diameters. Altogether, we quantified the mat biota of single subsamples from 33 cores. In this paper 'biomass' is expressed as biovolume $\left(\mathrm{nl} \mathrm{cm}^{-2}\right)$. Some individual species of protozoa were rare and often represented by only a single or a few cells per filter and the sampling error is therefore correspondingly large. For all major groups (e.g. ciliates, diatoms) SE is $<10 \%$.

In all cases, parallel samples were observed live under the light microscope. This yielded a more complete picture of the diversity and also allowed for the subsequent identification of most of the eukaryotes and of the large sulphur and cyanobacteria in the quantitative samples to the specific or generic level. Specimens representing all common species of protozoa were investigated systematically for food vacuole contents with special reference to sulphur bacteria which could often be identified and measured. Data on food preferences of ciliates were also drawn from Fenchel (1968). Some of the mat protozoa were also isolated in cultures and used for studies on chemosensory behaviour; these results are published elsewhere (Fenchel \& Bernard 1995a).

For electron microscopy small pieces of mat were cut free with a scalpel and fixed in 5\% glutaraldehyde, $1 \%$ $\mathrm{OsO}_{4}$ and $0.5 \mathrm{mM}$ sucrose in $50 \mathrm{mM}$ phosphate or MOPS buffer ( $\mathrm{pH} 7.4$ ) for about $0.5 \mathrm{~h}$ followed by washes in buffer and in distilled $\mathrm{H}_{2} \mathrm{O}$. For scanning electron microscopy (SEM) samples were critically point dried and coated with $\mathrm{Au}$ in a sputter coater. For transmission electron microscopy (TEM) samples were stained with uranyl acetate in $70 \%$ ethanol, dehydrated, embedded in epon and sectioned with glass knives (some minute mineral grains were always present) on an ultramicrotome. Observations (and photography) on freshly collected and intact microbial mats from above or from the side through transparent sampling cores were made with a dissection microscope. We used a $100 \mathrm{~W}$ halogen lamp fitted with fibre optics to provide focused, cold light as a light source.

\section{RESULTS AND DISCUSSION}

\section{Structure and composition of the mats}

The protected mat from the deep site in the harbour differed from the mats of the other 2 sites by its relatively constant composition of the biota and its high biovolume of sulphur bacteria. These were predominantly Beggiatoa; other forms (Thiovulum, Thiospira, Macromonas) were present (often seen in the food vacuoles of protozoa), but they were too few to be quantified. The mat was about $600 \mu \mathrm{m}$ thick; the total length of the Beggiatoa filaments ranged from about 10 to $70 \mathrm{~m}$ per $\mathrm{cm}^{2}$ mat and constituted a biovolume of 1000

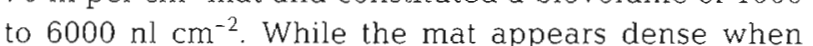
observed from above (Figs. $1 \mathrm{C} \& 2$ ), calculations showed that the volume fraction of the Beggiatoa filaments in fact only constituted $6.7 \%$ (range 3 to $13 \%$ ) of the mat, which thus had a high porosity. This was confirmed by 5 TEM sections through the mat (not shown) in which the surface fraction (= volume fraction) of transected filaments constituted $7.0 \%$ (range: 6.2 to $9.0 \%$ ). The calculated projected surface area of the filaments was 2.2 (range 0.6 to 5.0 ) $\mathrm{cm}^{2} \mathrm{~cm}^{-2}$ sediment surface area and the sediment was therefore not visi- 
ble through the mat. There was no evidence of a mucous matrix (Fig. 2) and the relatively weak mechanical coherence of the mat was probably only due to the entangled filaments.

Phototrophic microorganisms were responsible for

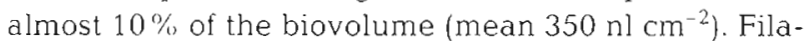
mentous cyanobacteria such as Oscillatoria spp, Phormidium-type filaments and Spirulina (total cyanobacterial filament length was about $5 \mathrm{~m} \mathrm{~cm}^{-2}$ ) dominated, but pennate diatoms and green euglenoids were also im- portant. In freshly collected mats the phototrophic constituents were found throughout and immediately below the Beggiatoa mat, but when the cores were left in diffuse daylight at room temperature the sulphur bacteria migrated downwards within an hour, leaving the brownish-green layer of phototrophs on the top. Phagotrophic protists included heterotrophic flagellates, lobose amoebae and the quantitatively dominating ciliated protozoa. The most common ciliates included microaerobic/aerobic forms like Euplotes
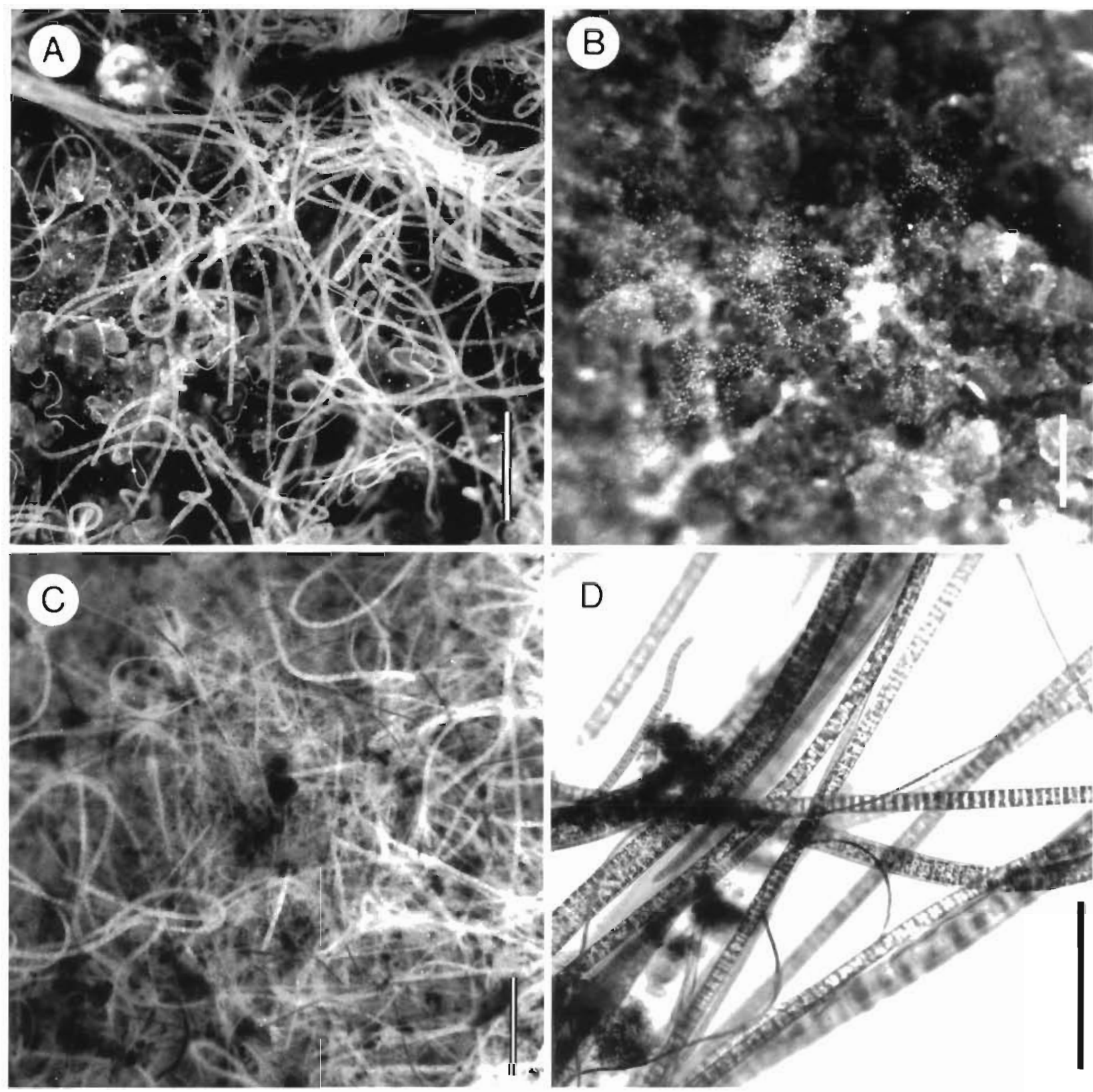

Fig. 1. (A-C) Surface of intact sediment cores. (A) Beggiatoa dominated mat, Nivâ Bay, Denmark (scale bar $=0.5 \mathrm{~mm}$ ) $(\mathrm{B})$ Thiovulum cells hovering about $100 \mu \mathrm{m}$ above the sediment, Niva Bay (scale bar $=0.25 \mathrm{~mm}$ ); $(\mathrm{C})$ microbial mat from the deep harbour site; dark fllaments are cyanobacteria (scale bar $=0.5 \mathrm{~mm}$ ). (D) Individual filaments of Beggiatoa and cyanobacteria (scale bar $=0.1 \mathrm{~mm}$ ) 

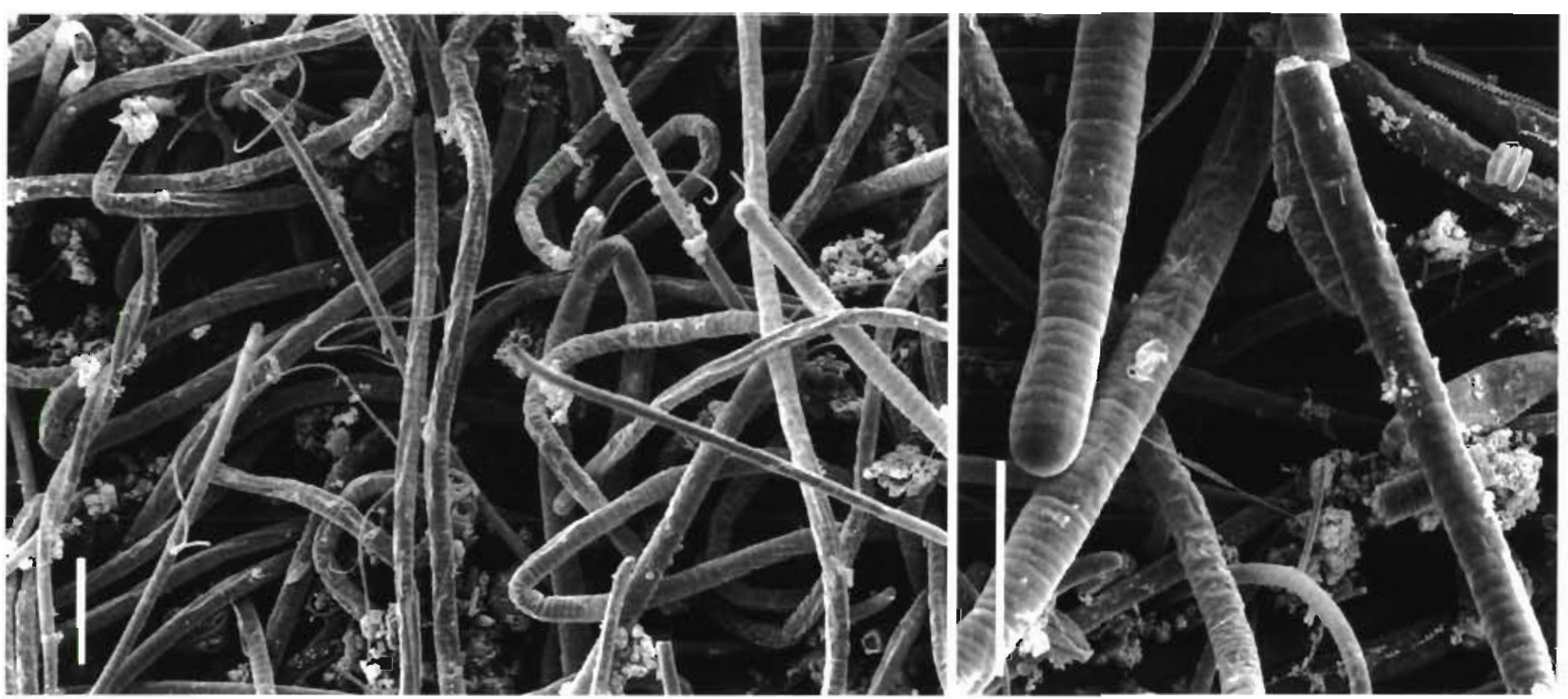

Fig. 2. SEM photographs of the mat surface, deep harbour site right panel also shows diatoms. Scale bars $=0.1 \mathrm{~mm}$

elegans, Uronema spp., Cyclidium spp., Peritromus faurei, Frontonia marina, Pleuronema coronatum and Pleuronema crassum, Paramecium calkinsi, LoxophylIum spp., and occasionally Condylostoma patulum.

Table 1. Constituents of quantitative samples from the deep site in the harbour 9 February 1995 (mean of four $0.096 \mathrm{~cm}^{2}$ samples) and from Niva Bay on 29 April 1994 (based on one $0.096 \mathrm{~cm}^{2}$ sample)

\begin{tabular}{|c|c|c|c|}
\hline \multicolumn{2}{|l|}{ Harbour site } & \multicolumn{2}{|l|}{ Nivå } \\
\hline & $\mathrm{m} \mathrm{cm^{-2 }}$ & & $\mathrm{m} \mathrm{cm}^{-2}$ \\
\hline Beggiatoa $2 \mu \mathrm{m}$ & 0.4 & Beggiatoa & 4.7 \\
\hline $\begin{array}{r}5 \mu \mathrm{m} \\
10 \mu \mathrm{m}\end{array}$ & $\begin{array}{r}65.9 \\
15\end{array}$ & & cells ml $\mathrm{m}^{-2}$ \\
\hline $30 \mu \mathrm{m}$ & 5.5 & Thiovulum & $2.5 \times 10^{5}$ \\
\hline \multirow{2}{*}{ Oscillatoria $\begin{array}{r}10 \mu \mathrm{m} \\
30 \mu \mathrm{m}\end{array}$} & 1.4 & Thiospira & $8.6 \times 10^{5}$ \\
\hline & 0.2 & Non-sulphur bacteria & $5.8 \times 10^{7}$ \\
\hline Phormidium & 0.2 & Diatoms & $1.0 \times 10^{5}$ \\
\hline \multirow[t]{2}{*}{ Spirulina } & 3.7 & Heterotrophic flagellates & $9.9 \times 10^{5}$ \\
\hline & cells $\mathrm{cm}^{-2}$ & Chlamydodon triquetrus & 104 \\
\hline Non-sulphur bacteria & $4.7 \times 10^{7}$ & Pleuronemasp. & 41 \\
\hline & $8.7 \times 10^{3}$ & $\begin{array}{l}\text { Uronema sp. } \\
\text { Uromation sp. }\end{array}$ & 291 \\
\hline \multirow{2}{*}{$\begin{aligned} & \text { Diatoms } 20 \mu \mathrm{m} \\
& 40 \mu \mathrm{m}\end{aligned}$} & $8.7 \times 10^{3}$ & Euplotes elegans & 203 \\
\hline & $1.2 \times 10^{4}$ & Litonotus $\mathrm{sp}$ & 21 \\
\hline Cyclidium spp. & 28 & Unidentified ciliates & 740 \\
\hline Euplotes elegans & 14 & & \\
\hline Loxophyllum sp. & 28 & & \\
\hline Frontonia marina & 164 & & \\
\hline Peritromus faurej & 494 & & \\
\hline Pleuronema sp. & 14 & & \\
\hline Uronema sp. & 95 & & \\
\hline Unidentified ciliates & 14 & & \\
\hline Nematodes & 338 & & \\
\hline
\end{tabular}

Anaerobic ciliates (presumably occurring largely on the underside of the mat) included Metopus spp., Plagiopyla frontata, Cristigera spp. and a Cyclidium sp. as the most common representatives. The composition of a sample is exemplified in Table 1 and the mean and range of biovolumes of the major microbial groups are shown in Fig. 3. Metazoan fauna were quantitatively poor in this locality. One sample revealed 315 nematodes $\mathrm{cm}^{-2}$ belonging to 3 species (Diplolaimelloides deconincki, Geomonhystera disjuncta and Sabatieria pulchra), the first 2 species occurring within the mat and the third immediately below it. Quantifying the animals from the surface layer of the complete core sample $\left(7.92 \mathrm{~cm}^{2}\right)$ further revealed 4.2 harpacticoids (Parastenhelia sp.), 1.9 turbellaria, and 0.3 rotifers (Notholca) $\mathrm{cm}^{-2}$. There were no signs of burrows of worms, molluscs or crustaceans in this sediment. The relative paucity of fauna was probably due to the fact that the water column immediately above the mat occasionally becomes anoxic or almost so (Fenchel \& Bernard 1995b).

The mats from Nivå Bay (and the similar mats from the shallow locality in the harbour) differed in many respects from that of the protected site. They were smaller (often only from a few to about $50 \mathrm{~cm}$ across) reflecting local, visible accumulations of degrad- 


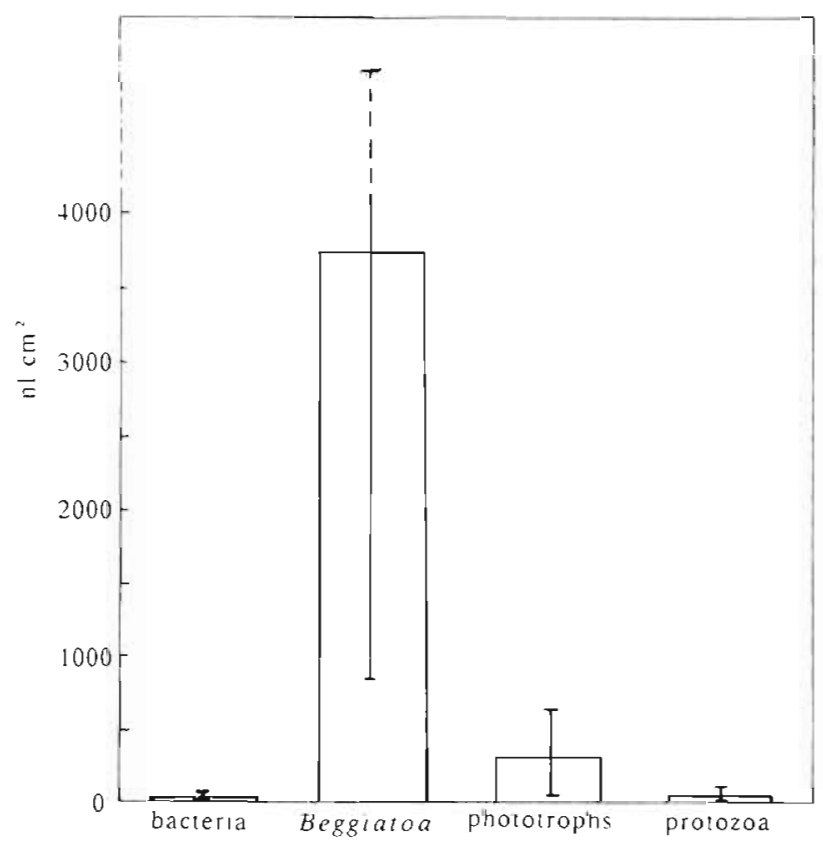

Fig. 3. Mean and range of biovolume of the major microbial groups from the deep harbour site based on 11 quantitative samples within the period January to March 1995. (Maximum volume of Beggiatoa was $-6000 \mathrm{nl} \mathrm{cm}{ }^{-2}$; cyanobacteria are included among the phototrophs; 'bacteria' refers to nonsulphur bacteria)

ing organic material in the underlying sediment and these mats were frequently destroyed by a high water level in conjunction with windy weather. The biovolume of sulphur bacteria of freshly collected samples was on the average only about $1 / 10$ of that of the protected Beggiatoa mats. Their composition was variable: sometimes the sulphur bacteria were represented only by Thiospira or by Thiovulum and filamentous bacteria were absent; in other cases, Beggiatoa dominated. When Thiovulum dominated, there were between 1.8 and $9.5 \times 10^{5}$ cells $\mathrm{cm}^{-2}$; this corresponded to a biovolume of 30 to $170 \mathrm{nl} \mathrm{cm}^{-2}$ and the projected surface area represented 7 to $36 \%$ of the surface of the sediment so that the underlying sediment was visible from above through the bacterial layer (Fig. 1B). The thickness of the Thiovulum layer was about $200 \mu \mathrm{m}$ and when the cells occurred at the highest densities they formed mucous veils as described elsewhere (Fenchel 1994). Even in the densest populations of Thiovulum the volume fraction of the cells in the $0.2 \mathrm{~mm}$ thick mat constituted only about $1 \%$. When Beggiatoa dominated, the biovolume made up of sulphur bacteria was higher (150 to $1120 \mathrm{nl} \mathrm{cm}{ }^{2}$ ); the projected surface area of the filaments was 5 to $100 \%$ of the sediment surface area. The mats were correspondingly thinner than those from the protected site and calculations show that the porosities of the mats were similar (Fig. 1A).
From autumn to spring, phototrophs (mainly diatoms, some filamentous cyanobacteria and phototrophic flagellates) constituted a biovolume which was comparable to or somewhat lower than that of the sulphur bacteria. During summer, however, the sediment surface was totally dominated by diatoms, filamentous cyanobacteria and purple sulphur bacteria and the white sulphur bacteria were only apparent on the sediment surface during night and early morning. Protozoan biovolume was comparable to that of the Beggiatoa mats from the harbour. Species diversity, however, was much higher and all the species listed in Table 2 have been found in the Niva Bay mats. Fig. 4 shows the mean biovolume of the major microbial constituents from Nivå Bay mats and Table 1 exemplifies the composition of a sample. Metazoan fauna included major meiofaunal groups like nematodes, harpacticoids, turbellarians and oligochaetes and macrofauna such as polychaetes (in particular juvenile Nereis diversicolor) and Corophium and Hydrobia spp.; these components were not quantified in the present study.

\section{Successional patterns}

During the study it was noted that in Nivå Bay, fresh patches of white sulphur bacteria (emerging 3 to $4 \mathrm{~d}$ after a stormy period) were dominated by small freeswimming bacteria (Macromonas, Thiospira, Thiovulum) while more mature patches were dominated by

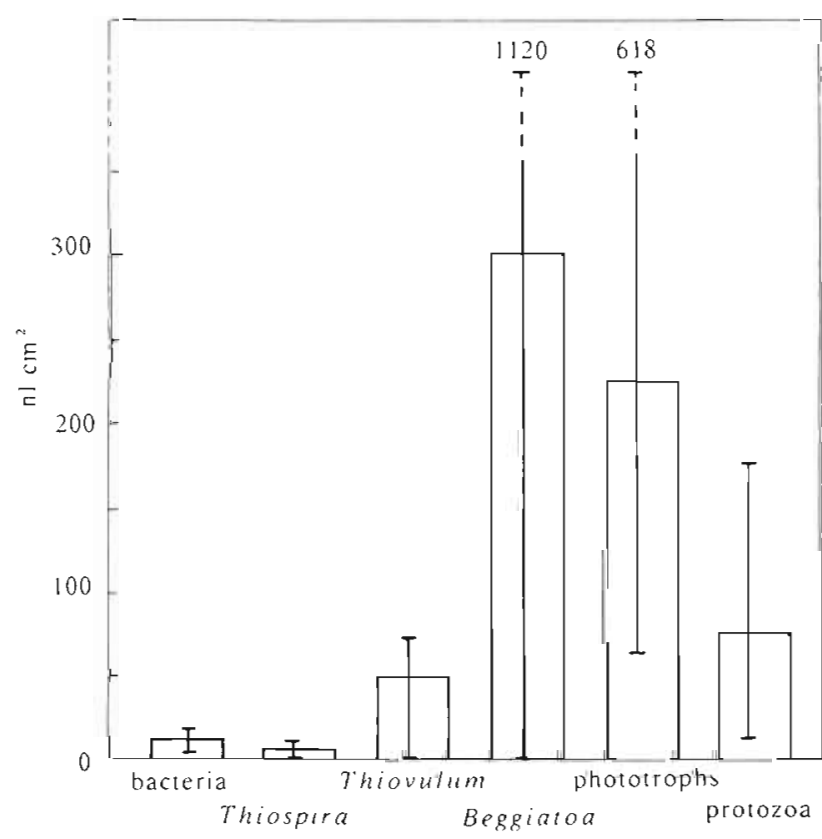

Fig. 4. Mean and range of biovolume of major microbial groups from Nivå Bay microbial mats based on 8 quantitative samples from April to May 1994 (cyanobacteria are included among phototrophs; 'bacteria' refers to non-sulphur bacteria) 
Table 2. Phagotrophic protists recorded from mats of colourless sulphur bacteria. Amoebae will be reported separately (A Smirnov unpubl.)

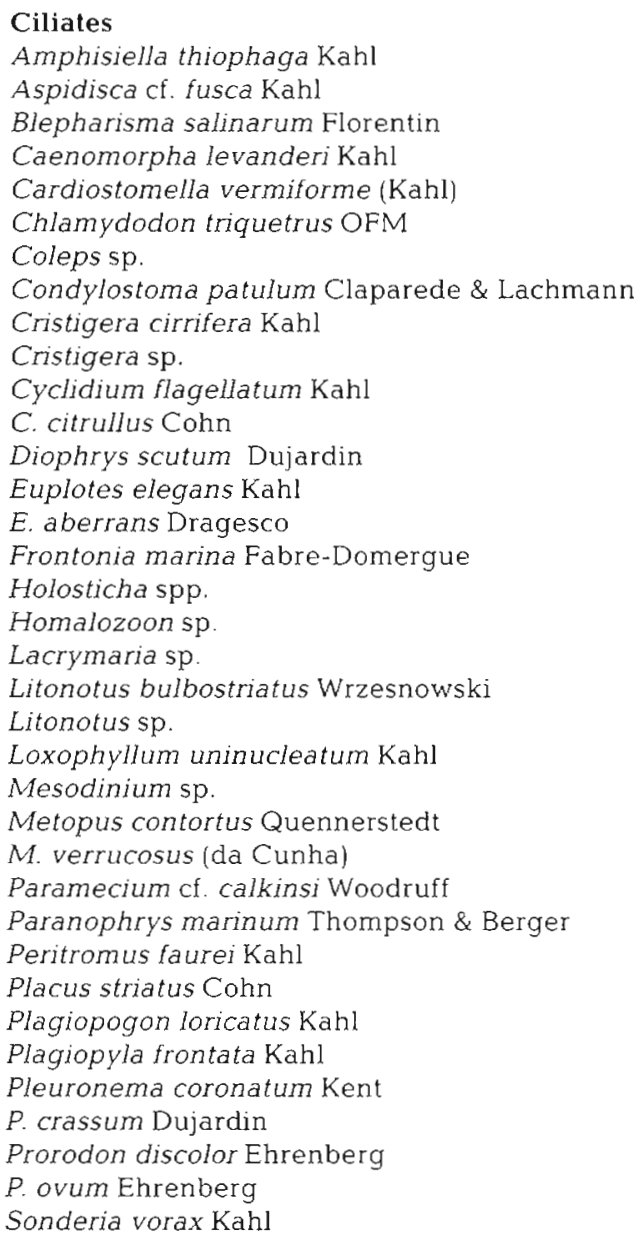

\author{
Sonderia spp. \\ Spathidium fresenburgi Kahl \\ Strombidium cinctum Kahl \\ S. elegans Florentin \\ S. sauerbreyae Kahl \\ S. styliferum Levander \\ S. cf. sulcatum Claparede \& Lachmann \\ Tracheloraphis sp. \\ Trochiloides recta Kahl \\ Uronema filificum Kahl \\ U. marinum Dujardin \\ Uronychia transfuga OFM
}

\author{
Flagellates \\ Amastigomonas debruynei de Saedeleer \\ A. mutabilis Patterson \& Zölffel \\ Bicosoeca sp. \\ Bodo curvifilus Griessman \\ Bodosp. \\ Bordnamonas tropicana Larsen \& Patterson \\ Cafeteria roenbergensis Fenchel \& Patterson \\ Ciliophrys marina Caullery \\ Dinema littorale Skuja \\ Gymnodinium sp. \\ Massisteria marina Larsen \& Patterson \\ Mastigameobasp. \\ Metromonas grandis Larsen \& Patterson \\ Paraphysomonas sp. \\ Percolomonas cuspidata Larsen \& Patterson \\ Petalomonas sp. \\ Pteridomonas danica Patterson \& Fenchel \\ Pyramimonas sp. \\ Unidentified ( 1 species)
}

Lobose amoebae

Several species filamentous forms. In order to study this in more detail a sediment core was collected after a windy period. In the laboratory it was placed in dim light at $\sim 20^{\circ} \mathrm{C}$, and the supernatant $2 \mathrm{~cm}$ of water was bubbled with atmospheric air. The development of the surface biota was then followed for $10 \mathrm{~d}$ (Fig. 5). It can be seen that free-swimming sulphur bacteria (and the thinnest filamentous forms) dominated initially, but they were eventually displaced by larger Beggiatoa filaments. After the appearance of the largest filaments the total biovolume of sulphur bacteria increased drastically and eventually the mat resembled that found in the protected site in the harbour.

There may be 2 (not mutually exclusive) explanations for this pattern. The free-swimming bacteria (and especially Thiovulum have a high motility and are capable of a faster colonisation of suitable sites. It is also conceivable that during the initial stages of the succession (which is based on the anaerobic degrada- tion of buried organic material) the supply of sulphide will change relatively quickly over time and that the free-swimming bacteria are superior in terms of tracing vertical migrations of the chemocline rapidly; in contrast to the filamentous forms they are also capable of following the chemocline above the sediment surface. Conversely, and since Beggiatoa (but not Thiovulum) tolerates anoxia (Nelson et al. 1986b, Nelson 1989, Fenchel 1994), it is conceivable that the filamentous forms eventually monopolise the sulphide supply once the chemocline has been stabilised at or immediately beneath the sediment surface. It is also possible that selective grazing plays a role for the successional patterns of different sulphur bacteria. As discussed below, there are numerous protozoa which thrive on free-swimming sulphur bacteria; when these appear, dense populations of ciliates develop and decimate the bacterial populations within 1 to $2 \mathrm{~d}$. In contrast few species feed on filamentous forms and we have not 
found any protozoon capable of feeding on larger (diameter $>10 \mu \mathrm{m}$ ) Beggiatoa filaments.

Systematic measurements of fluxes of sulphide and of oxygen (Fenchel \& Bernard 1995b) showed that the rate of $\mathrm{S}^{2-}$ oxidation was not higher in mats of filamentous sulphur bacteria as compared to Thiovulum or Thiospira mats although the former represent a biovolume which may be up to 70 -fold higher. The weightspecific respiratory rate (and thus specific growth rate) of the large Beggiatod filaments must consequently be correspondingly lower than that of smaller sulphide oxidisers. Fenchel \& Bernard (1995b) found that a typical figure for the chemoautotrophic production by bacterial mats is $2.5 \mu \mathrm{mol} \mathrm{C} \mathrm{cm} \mathrm{C}^{-1}$. The percentage of dry weight of the bacteria is unknown and probably lower for the larger forms, in which most of the volume is taken up by vacuoles. If we assume $10 \%$ to be a reasonable guess then the production of a Thiovulum mat would correspond to about 11 times the biomass $\mathrm{d}^{-1}$ ( 3 to 4 cell doublings $\mathrm{d}^{-1}$ ) while the thickest Beggiatoa mats only produce about $17 \%$ of the bacterial biomass $\mathrm{d}^{-1}$ This difference may be apparent and only reflect that the largest sulphur bacteria are strongly vacuolated and, in fact, represent a considerably smaller amount of dry matter than suggested by their volume. This is the case for giant hydrothermal vent Beggiatoa (Jannasch et al. 1989), and it also applies to the somewhat smaller shallow-water forms (Fenchel unpubl. obs.). On the other hand, Nelson et al. (1986b) found that the increment in biomass (in terms of dry weight) of Beggiatod in pure cultures ranged between only 17 and $31 \%$ in $24 \mathrm{~h}$, and so it is also possible that these organisms have an innate low growth potential or that competition for sulphide or for oxygen limits growth in the thick mats.

\section{Vertical zonation of the associated biota}

The thickness of the bacterial mats could be measured directly and ranged between 0.2 and $0.6 \mathrm{~mm}$. This accords with the behaviour of cultures of sulphur bacteria observed in steep $\mathrm{O}_{2}$ gradients in the laboratory (Nelson et al. 1986b, Fenchel 1994).

It is less easy to demonstrate that the associated protozoan biota also show such sharp zonation patterns. In the laboratory it has been shown that several species isolated from mats of sulphur bacteria are capable of maintaining 0.2 to $0.8 \mathrm{~mm}$ sharply delimited bands in $\mathrm{O}_{2}$ gradients with a steepness characteristic of the mats (Fenchel \& Bernard 1995a). However, while it is possible to isolate the mat itself (although some supernatant water and some underlying sediment is usually included) it is very difficult to take samples above and below the mat with a vertical resolution of $<1 \mathrm{~mm}$.

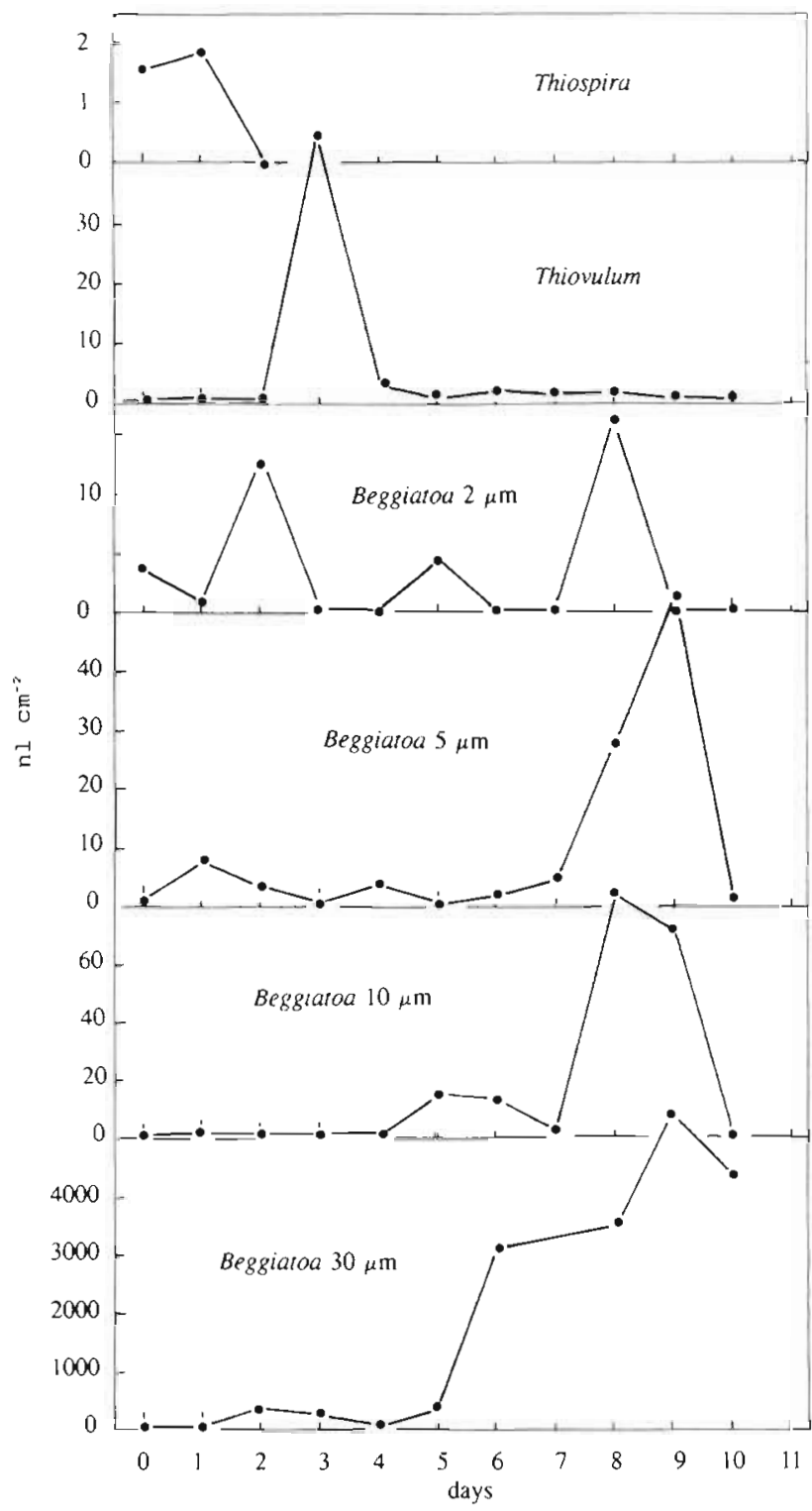

Fig. 5. Succession in the occurrence of different types of colourless sulphur bacteria in a core from Nivå Bay

Table 3 shows an example in which we isolated a Thiovulum film hovering immediately above the sediment (this sample was assumed to be $\sim 1$ mm thick), the overlying $4 \mathrm{~mm}$ of water and the upper $2 \mathrm{~mm}$ of underlying sediment. The concentration of protozoa in the Thiovulum layer (almost $10^{5} \mathrm{ml}^{-1}$ ) was considerably higher than in the underlying sediment and in the overlying water. This probably underestimates the true density in the mat which was considerably thinner than $1 \mathrm{~mm}$. Previous studies have shown that the zone of chemautotrophic production harbours increased densities of phagotrophic organisms (Fenchel 1969), but the spatial resolution of the sampling was less fine and so the effect seemed less dramatic. 
Table 3. Density (cells $\mathrm{ml}^{-1}$ ) of major groups of microbes in the $4 \mathrm{~mm}$ water column above, within and in the $2 \mathrm{~mm}$ layer beneath a Thiovulum mat; shallow site in the harbour, 30 May 1994

\begin{tabular}{|c|c|c|c|}
\hline & Above mat & Within mat & Below mat \\
\hline Thiovulum & $3.4 \times 10^{4}$ & $9.9 \times 10^{5}$ & $1.5 \times 10^{5}$ \\
\hline Bacteria & $5.1 \times 10^{8}$ & $6.4 \times 10^{9}$ & $2.1 \times 10^{9}$ \\
\hline Diatoms & 100 & $4.8 \times 10^{6}$ & $1.8 \times 10^{5}$ \\
\hline Protozoa ${ }^{a}$ & 800 & $9.1 \times 10^{4}$ & $8.5 \times 10^{3}$ \\
\hline \multicolumn{4}{|c|}{$\begin{array}{l}\text { a Mainly ciliates (dominated by Uronema marinum, Euplo- } \\
\text { tes elegans, Cyclidium sp.) and some heterotrophic dino- } \\
\text { flagellates }\end{array}$} \\
\hline
\end{tabular}

Fenchel \& Bernard (1995a) found that different species of ciliates showed differential preferences for $\mathrm{O}_{2}$ tension (somewhere within the range of 1 to $20 \%$ atmospheric saturation). It could therefore be expected that there is some zonation of ciliate species within the mat, but we could not demonstrate this. The only exception were the obligatory anaerobic ciliates, which occurred mainly beneath the mats.

\section{Consumption of sulphur bacteria by phagotrophs}

The mineralisation of the chemoautotrophic production in the microbial mats from the deep harbour site and from Nivå Bay accounts for about $50 \%$ and 10 to $30 \%$, respectively, of the $\mathrm{O}_{2}$ consumption of aerobic heterotrophs (Fenchel \& Bernard 1995b). This indicates that the phagotrophic food chains of the mats are to a large extent fuelled by chemoautotrophic production.

In the studied mats the main consumers of the sulphur bacteria are the ciliates in which the remains of sulphur bacteria are easily identified in feeding vacuoles. The ciliates show a considerable variation with respect to food particle preferences. In the microbial mats many are specialised on diatoms, dinoflagellates or smaller flagellates, on unspecified bacteria or on other ciliates. With respect to sulphur bacteria a considerable number of ciliate species feed exclusively or predominantly on Thiovulum in these mats. These include Euplotes elegans, Paramecium cf. calkinsi, Pleuronema crassum, Pleuronema coronatum, Blepharisma salinarum, Amphisiella thiophaga and an unidentified Keronopsis sp. (Fig. 6B, C). In particular, the Euplotes, Paramecium and/or the Pleuronema spp. often quantitatively dominate the protozoan biota (Table 1). Smaller sulphur bacteria (Macromonas, Thiospira) are especially consumed by the Uronema and Cyclidium spp. and by Blepharisma salinarum. In core samples or enrichment cultures a mass development of Thiovulum or of smaller, free-swimming sulphur bacteria is rapidly followed by blooms of one or more ciliate species feeding on and decimating the bacterial populations. It is therefore also likely that populations of these sulphur bacteria are controlled through ciliate grazing in the field. There are fewer species of ciliates which
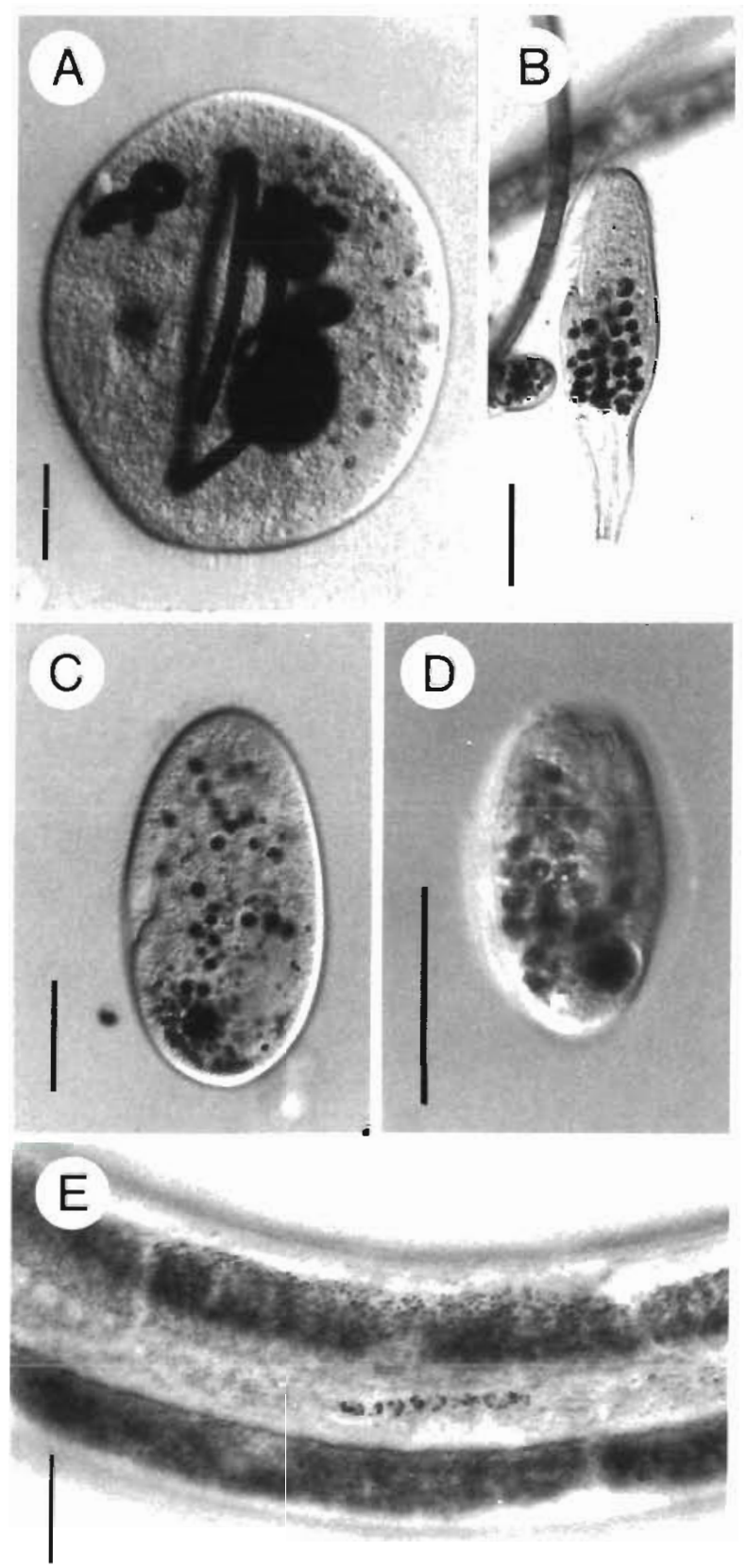

Fig. 6. Feeding on sulphur bacteria. (A) Squeezed Frontonja marina cell with ingested Beggiatoa filaments; $(B, C)$ Blepharisma salinarum and Paramecium cf. calkınsı with ingested Thiovulum cells; (D) Trochiloides recta with remains of ingested filamentous sulphur bacteria: (E) the nematode Diplolaimelloides deconincki with an ingested Beggiatoa filament. Scale bars: $(A-D)=50 \mu m_{i}(E)=100 \mu \mathrm{m}$ 
depend on filamentous forms. The only common ones are Frontonia marina (which also feeds on filamentous cyanobacteria and large diatoms) and Trochiloides recta, which seems to specialise on this diet (Fig. 6A, D). In addition the nematode Diplolaimelloides deconincki was observed to feed on filamentous sulphur bacteria in the mats at the harbour site (Fig. 6E). In no case, however, did we observe any organism which feeds on Beggiatoa filaments with a diameter exceeding $\sim 10 \mu \mathrm{m}$. In addition to the above-mentioned aero$\mathrm{bic} / \mathrm{microaerobic} \mathrm{species,} \mathrm{some} \mathrm{of} \mathrm{the} \mathrm{anaerobic} \mathrm{cili-}$ ates occurring immediately beneath the mats consume unicellular or filamentous colourless sulphur bacteria. The former are eaten especially by Metopus contortus and Plagiopyla frontata while filamentous forms $(<10 \mu \mathrm{m})$ are eaten by some of the Sonderia spp. (see also Fenchel 1968). The role of heterotrophic flagellates and lobose amoebae as consumers of sulphur bacteria was not studied systematically; very rarely did we find sulphur granules in their vacuoles and due to their small size they would not be capable of ingesting the larger and morphologically identifiable forms of sulphur bacteria.

In the harbour site the above-mentioned list of grazers of sulphur bacteria is probably almost complete; the apparent absence of protozoa or meiofauna species which consume the large $\sim 30 \mu \mathrm{m}$ Beggiatoa filaments probably explains the dominance of these bacteria at this site. In the Nivå Bay localities the mats are not only inhabited by the protozoan biota, but also by a variety of meio- and macrofauna; their role as consumers of sulphur bacteria and other components of the microbial mats remains to be studied.

Acknowledgements. The study was supported by the Danish Natural Science Research Council (0088-1) and the European Union (MAST programme 93-0058). We are grateful to Mr Ib Aagaard for collecting samples by SCUBA diving, to $\mathrm{Dr}$ Preben Jensen for identification of the nematode species from the harbour site and to Dr Claus Lundsgaard and Ms Lisbeth Thrane Haukrogh for help with specimens for the SEM observations.

This article was submitted to the editor

\section{LITERATURE CITED}

Fauré-Fremıet E (1951) Associations infusoriennes à Beggiatoa. Hydrobiologia 3:65-71

Fenchel T (1968) The ecology of marine microbenthos II. The food of marine benthic ciliates. Ophelia 5:73-121

Fenchel T (1969) The ecology of marine microbenthos IV Structure and function of the benthic ecosystem, its chemical and physical factors and the microfauna communities with special reference to the cillated protozod. Ophelia 6 : $1-182$

Fenchel T (1994) Mobility and chemosensory behaviour of the sulphur bacterum Thiovalum majus. Microbiology 140: 3109-3116

Fenchel T, Bernard C (1995a) Behavioural responses in oxygen gradients of ciliates from microbial mats. Eur J Protistol 31 (in press)

Fenchel T, Bernard C (1995b) Mats of colourless sulphur bacteria. 1. Major microbial processes. Mar Ecol Prog Ser 128: $161-170$

Jannasch HW, Taylor CD, Wirsen CO (1989) Massive natural occurrence of unusual large bacteria (Beggiatoa sp.) at a hydrothermal deep-sea vent site. Nature 342:834-836

Jørgensen BB (1977) Distribution of colorless sulfur bacteria (Beggiatoa spp.) in a coastal sediment. Mar Biol 41:19-28

Moller MM, Nielsen LP, Jørgensen BB (1985) Oxygen responses and mat formation by Beggiatoa spp. Appl environ Microbiol 50:373-382

Nelson DC (1989) Physiology and biochemistry of filamentous sulfur bacteria. In: Schlegel HG, Bowien B (eds) Autotrophic bacteria. Springer-Verlag, Berlin, p 219-238

Nelson DC, Jorgensen BB, Revsbech NP (1986a) Growth pattern and yield of a chemoautotrophic Beggiatoa sp. in oxygen-sulfide microgradients. Appl environ Microbiol 52:225-233

Nelson DC, Revsbech NP, Jørgensen BB (1986b) Microoxicanoxic niche of Beggiatoa spp.: microelectrode survey of márine and freshwater strains. Appl environ Microbiol 52: $161-168$

Perkins EJ (1958) The food relationships of the microbenthos with particular reference to that found at Whitstable, Kent. Ann Mag natl Hist 13 (Ser 1):64-77

Stein JL (1984) Subtidal gastropods consume sulfur oxidizing bacteria: evidence from coastal hydrothermal vents. Sc1ence 223:696-698

Thane-Fenchel A (1968) The ecology and distribution of nonplanktonic brackish-water rotifers from Scandinavian waters. Ophelia 5:273-297

Tunnicliffe V (1991) The biology of hydrothermal vents: ecology and evolution. Oceanogr mar biol A. Rev 29:319-407

Manuscript first received: May 9, 1995

Revised version accepted: June 9, 1995 